\title{
Application of Licensing Services Electronic Based Construction Services Business
}

\author{
Sri Umiyati \\ Faculty of Social and Political Sciences, \\ Hang Tuah University, Surabaya Indonesia \\ M. Husni Tamrin \\ Faculty of Social and Political Sciences, \\ Hang Tuah University, Surabaya Indonesia \\ Debby Gita Maharani \\ Faculty of Social and Political Sciences, \\ Hang Tuah University, Surabaya Indonesia
}

\begin{abstract}
This research main goals are describring and analyzing service application based on electronic (Descriptive Study on Bussiness Permit Licensing for Construction Service in One-stop Integreted Service Unit in Surabaya). This research uses descriptive method with qualitative approachment. The theory that is used for analyzing on this research is e-Service Quality theory that consist of 7 dimension that are Website Design, Reliability, Responsiveness, Security/Privacy, Costumization, Information, and Ease of Use. The research result shows that application of Business Permit Licensing based on electronic is good. The dimensions that have shown the application of electronic-based services are good, namely in the dimensions of Responsiveness, Security / Privacy, Customization, Information, Ease of Use. The dimensions that show the application of services that are still not good, namely the dimensions of Website Design and Reliability.
\end{abstract}

Keywords: Application, Electronic Service, The Licensing of Business Permit for Construction Service

\section{INTRODUCTION}

The issue of public service is now an important issue in public service providers in Indonesia where the conditions of development of science and technology are increasingly advanced and increasingly fierce global competition. Service as a process of fulfilling needs through other people's activities directly, is a concept that is always actual in various institutional aspects. Not only in business organizations, but has developed more broadly in the order of government organizations (Sinambela, 2010: 42).

At present public services are not only provided with a face to face method where the public must directly face the relevant section. Besides requiring longer time, it also consumes a higher cost (high cost economy). Not to mention the phenomenon of unexpected intermediaries known as "brokers" and illegal levies (levies) which are considered to be very unsettling for the community, because the community must pay costs outside of the officially determined administrative costs. 
This is of course a consideration of the government to implement the concept of electronicbased governance to improve the quality of public services.

The City Government of Surabaya is not only able to implement the policy as mere formality, but more than that the City Government of Surabaya has become a pilot project model for other regions in Indonesia in implementing an online-based system for its government. (Source: e-book Profiles of Leaders for Change in 2018; p. 11). UPTSA is a government agency engaged in the field of public services more specifically serving licensing, in accordance with the sound of article 6 Surabaya Mayor Regulation Number 28 of 2007, which experienced the 3rd change namely Number 8 of 2010 concerning the Organization of the One-Stop Integrated Service Unit (UPTSA) City Surabaya. This centralization of licensing is aimed at making it easier for the applicant to take care of licensing. The applicant no longer needs to come to the agencies to take care of various licensing requirements.

The Surabaya City Government does not stop innovating from there to improve services at UPTSA, which is making an online system to facilitate business licensing and accelerate licensing services. The Surabaya City Government launched an online licensing management program named Surabaya Single Window (SSW). Surabaya Single Window (SSW) is one of the Surabaya city government licensing management services that is integrated online. This program aims to facilitate licensing services for the community with the Surabaya city government. With this online licensing, the positive impact that will be generated is the efficiency and effectiveness of bureaucratic performance.

Online licensing services that received awards and references for other regions turned out to still have an evaluation record from the Commissioner of the East Java Public Service Commission, Hardley Stefano said the features or applications in the SSW online licensing service and the One Stop Integrated Service (PTSP) need to be added to the satisfaction survey in order to know the extent of the performance of services provided by the Surabaya City Government. This satisfaction survey is important to do on the application as feedback. So, when the applicant receives his licensing documents, the applicant will immediately convey whether satisfied, quite satisfied or not satisfied in taking care of the permit, thus the results are connected in real time. (Source: news24.bisnis.com)

In addition, in the implementation of SSW online licensing, there are still complaints from applicants accessing licenses on the SSW such as the slow network of the SSW website when uploading licensing documents. In addition, the applicant's uncertainty in providing the corrections to the documents was also felt by the applicant. (Source: Jawa Pos, 19 May 2018).

Based on the phenomena that occur above, it is necessary to observe to see the current conditions. From the results of the pre-observations made, it can be obtained that the SSW Licensing and Non-Licensing Services in the Construction Services Business Licensing license experienced a file delay of $73.13 \%$ in 2017 . The existence of this phenomenon will therefore need an analysis of the application of services on the SSW website online system, so that the applicant can receive the file in accordance with the specified time. As SSW functions that make it easy for people to take care of licensing online without having to go back and forth to the UPTSA office.

Based on the above background, the formulation of the problem to be investigated is "How is the Application of Electronic-Based Licensing Services (Descriptive Study in Licensing Services for Construction Services Business Licenses in the One-Stop Integrated Service Unit of Surabaya, East Java, Indonesia)?". 


\section{LITERATURE REVIEW}

According to Law Number 25 of 2009 concerning Public Services is an activity or series of activities in the framework of meeting service needs in accordance with statutory regulations for every citizen and resident of goods, services, and / or administrative services provided by public service providers.

The definition of public services according to the Ministerial Decree PAN Number 25 of 2004 is all service activities carried out by public service providers as an effort to meet the needs of service recipients, as well as in the context of implementing the provisions of the legislation. Whereas Kepmen PAN No. 58/2002 groups three services from agencies as well as BUMN / BUMD. The grouping of types of services is based on the characteristics and nature of the activities and products produced, namely (1) administrative services, (2) goods services, (3) services.

\section{E-service Quality}

Quality of service in the online environment becomes important in determining the success or failure of electronic commerce. Voss (2003) defines services in an electronic environment (eservice) as "the delivery as a service using new media such as the web", the definition means the delivery of services using new media, namely the website. The existence of evidence of service quality for submission via the website is a very important success strategy compared to low prices and the existence of the website (Zeithaml et al., 2002).

The quality of online services in its interaction with the website is "the extent to which a website facilities are efficient and effective shopping, purchasing and delivery". Explanation of the definition is interpreted as a level of a website to effectively and efficiently facilitate shopping, making purchases and the delivery process of products and services. Website quality assessment is not only the experience during interaction with the website but also the interaction after getting service (Parasuraman et al, 2005)

\section{Dimensions of Electronic Service Quality (E-Service Quality)}

The 7 dimensions of eane service quality Alanezi, et al (2010) in Alvaro, et al (2014), namely:

1) Website design: Technical operations and appearance of the Website

2) Reliability: The satisfaction towards a timely delivery of the service. For instance, the action of emailing or contacting the customer by phone, increasing the trust in the delivery of the right products with appropriate charges. (Reliability: Satisfaction with the timely delivery of services. For example, the act of using e-mail or contacting customers via telephone, increasing confidence in delivering the right product at the right cost).

3) Responsiveness: If the delivered service was truly useful and was not delayed. If the service actually answers questions in a useful and timely manner. (Reaction ability: If the service delivered is truly useful and not delayed. If the service really answers the question with useful and appropriate answers).

4) Security / Privacy: The level of security and personal data protection users offer by government Websites. (Security / Privacy: The level of security and protection of user personal data offered by government websites).

5) Customization: The will to provide services with special care and individualized attention to consumers. In the SERVQUAL methodology this dimension is referred to as empathy, but it is not focused on electronic services. According to Alanezi, Kamil and Basri (2010), this change takes place because online services do not provide a direct contact between the client and the staff. (Customization: Willingness to provide services with special care and individual attention to consumers. In the SERVQUAL methodology 
this dimension is called empathy, but is not focused on electronic services. According to Alanezi, Kamil and Basri (2010), this change occurs because online services do not require direct contact between client and staff).

6) Information: Information provided by the online service. It must be accurate, current and easy to understand. (Information: Information provided by the service must be accurate, current and easy to understand).

7) Ease of use: The ease of use level of Websites. Any Website should be user friendly, in order to guarantee his satisfaction. (Ease of use: Ease of use of Websites. Every Website must be user friendly, to ensure satisfaction).

\section{Types Relations of E-Government}

According to Indrajit in Rianto (2012) in his book POLRI and E-Government Applications, explaining the types of relations in E-Government can be divided into four types as follows:

\section{A. Government to Citizens (G-to-C)}

This type of G-to-C is the most common E-government application, where the government builds and implements various information technology portfolios with the primary goal of improving information with the primary goal of improving the relationship of interaction with the public. In other words, the main purpose of developing a G-to-C type e-Government application is to bring the government and its people closer to a variety of access channels so that the community can easily reach their government to meet various daily service needs.

\section{B. Government to Business (G-to-B)}

One of the main tasks of a government is to establish a conducive business environment so that a country's economic wheels can run as they should. In carrying out their daily activities, business entities such as private companies need a lot of data and information owned by the government. Besides that, he must also interact with various state institutions because it is related to the rights and obligations of his organization as a profit-oriented entity. The need for good relations between the government and business circles not only aims to expedite business practitioners in running the wheels of their companies, but furthermore many things can benefit the government in the case of good and effective interaction with the private industry.

\section{Government to Government (G-to-G)}

In this era of globalization, it is clear that there is a need for countries to communicate more intensely with each other day by day. The need to interact between one government and the government every day not only revolves around things that smell of diplomacy alone, but furthermore to facilitate cooperation between countries and cooperation between state entities (society, industry, companies, etc.) in doing matters relating to trade administration, political processes, mechanisms of social and cultural relations, and so forth.

\section{Government to Employes (G-to-E)}

In the end, e-Government applications are also intended to improve the performance and welfare of civil servants or government employees who work in a number of institutions as public service.

By being aware of the various types of e-Government relations, the strategic functions of various e-Government applications developed can be seen by a country. Its existence is not only to improve the performance of government services to the community, but even further to improve the quality of government administration of a country, which ultimately leads to the progress of the country itself. 
Dengan menyadari adanya bermacam-macam tipe relasi e-Government tersebut, maka terlihat fungsi strategis dari berbagai aplikasi e-Government yang dikembangkan oleh sebuah negara. Keberadaannya tidak hanya semata untuk meningkatkan kinerja pelayanan pemerintah kepada masyarakatnya, namun lebih jauh lagi untuk meningkatkan kualitas dari penyelenggaraan pemerintahan sebuah negara, yang pada akhirnya bermuara pada kemajuan negara itu sendiri.

\section{RESEARCH METHODS}

This type of research used in this research is descriptive research. The approach used is qualitative research. The primary data in this study is the interview guide as an interview guide to interview the applicant and IUJK licensing officer at UPTSA Surabaya. Secondary data in this study are books, literature, journals, and articles related to the Construction Services Business License (SIUJK) and the Surabaya Single Window program in the Integrated Service Unit of the City of Surabaya. Data collection techniques are done through observation, interviews, documentation. In this study using data analysis techniques proposed by Miles, Huberman, and Saldana consisting of data collection, data condensation, data presentation, conclusion / verification.

\section{A. Website Design}

\section{RESULTS AND DISCUSSION}

Website design, is the quality of website design in this study can be seen from the visual appearance and technical operation of the website or website of the Construction Services Business Licensing licensing service through the SSW website in the Surabaya One-Stop Integrated Services Unit in Surabaya. The visual and organized appearance of the SSW website on the IUJK licensing service is already good, that is, it has a good and clear appearance and is well organized according to the licenses of various SKPDs. This can be seen in the selection icon that can be used by the applicant to find a lightened licensing service. That way the applicant is easier to use licensing services through online.

While on the technical side the SSW website is still lacking because there is still a long loading when uploading IUJK licensing files, even though the SSW server has been able to accommodate large files up to $100 \mathrm{MB}$. But in reality, the applicant complained about the long loading when uploading the file. The slow process of uploading data can be related to the applicant's internet connection. Thus the results of the analysis on the SSW Website Design at UPTSA Kota Surabaya are still felt to be lacking because of the long loading when the applicant uploaded the IUJK permit file.

\section{B. Reliability}

Reliability, is satisfaction with the timely delivery of services. In this research is related to the timeliness of IUJK licensing completion, and provides information on the results of file verification via SMS and E-mail. Based on Surabaya City Regulation Number 8 of 2011 Concerning Business Services Construction Permits in Article 9, the deadline that has been determined is no later than 7 working days since the application letter was received completely and correctly. However, what happened to the timeliness of the IUJK licensing completion was still felt to be inadequate in providing timely services to the applicant. It can be seen from the mismatch in completing the file on the SSW website that is 7 working days. Delays in the completion of the file that occurs is caused by an error of the requestor who entered the wrong data or technical error on the server.

Furthermore, the SSW website is already good at providing information on the results of verification of the IUJK file via e-mail or SMS. The Surabaya Single Window website effort to 
contact IUJK online licensing service applicants shows that licensing guarantees that it can provide the right services by giving notifications or notifications related to the licensing process. Thus the results of the analysis on the SSW website Reliability at UPTSA Kota Surabaya are still felt to be lacking because there is still a delay in the completion of the IUJK permit file which should be finished 7 working days.

\section{Responsiveness}

Responsiveness, is referring to the extent to which the services provided by the e-government website are very helpful and there is no delay in responding to the applicant. In the management of IUJK seen by researchers, it is related to how every question and complaint of the IUJK permit applicant can be accommodated and get an appropriate and fast response. On the SSW website service has provided contact information that is via telephone to contact officials from the IUJK licensing. In addition, interactive facilities provided by the applicant to convey criticism and suggestions as well as ask questions about the permit file can be via the UPTSA Surabaya City website at www.uptsa.surabaya.go.id. This shows that there is an effort in helping the applicant to submit questions and complaints or complaints related to IUJK licensing services, so that the applicant no longer needs to come to UPTSA Surabaya to ask questions or complaints.

Furthermore, the response given by the applicant if in the process of experiencing an error is also well informed, that is if the applicant makes a mistake or lacks files in the IUJK licensing service process, then the applicant will get a notification via e-mail or sms, so that the applicant can correct his mistake and repeat again the process from the start. Thus the results of the analysis on the Responsiveness dimension of the SSW website at UPTSA Surabaya have been good in helping and there was no delay in responding to the applicant.

\section{Security / Privacy}

Security / Privacy, is the level of security and protection of users' personal data offered by government websites. In the quality of IUJK licensing services at UPTSA Kota Surabaya, this dimension refers to the extent to which these services can provide trust by ensuring the security and personal information of IUJK online licensing applicants. In the guarantee of data security the applicant is safe enough because the SSW website has been equipped with a security system to prevent data theft. The security guarantee is the use of a password and email verification. The use of passwords on the SSW website is to ensure that only internal parties from the Surabaya Public Works and Spatial Planning Office can access the data or documents from the applicant. That way the system or website used in IUJK's online licensing service will be protected from data theft and burglary access to this service. E-mail verification will also guarantee that only the applicant can access it, because by using e-mail verification, the applicant will get an access code to access the IUJK online licensing service.

Furthermore, the protection of the applicant's personal information will be protected by not sharing data with outsiders or other sites. The existence of UPTSA Surabaya City officials is only accompanying the applicant without direct contact related to the applicant's personal information. Thus the results of the analysis on the Security / Privacy dimension on the SSW website are already good, namely the use of a security system and the protection of users' personal data offered by the SSW website.

\section{E. Coztumisation (Customization)}

Costumization refers to the extent to which a government website provides various services to ensure the specific needs of the applicant. In the management of IUJK seen by researchers, the ability of SSW services to accommodate the needs of the applicant. On the SSW website service 
has provided contact information that can be used by the applicant that is there is a telephone number, fax, and e-mail that can be used by the applicant if experiencing difficulties during the service process.

Furthermore, the website has provided the option of taking permit files, namely IUJK permits can be taken through UPTSA Central Surabaya and UPTSA East Surabaya, making it easier for the applicant and reaching the applicant closer when taking the file in accordance with the wishes of the applicant. Thus the results of the Coztumisation dimension analysis on the SSW website have provided various services to assure the needs of the applicant.

\section{F. Information}

Information is information provided by the service must be accurate, current and easy to understand. In the management of IUJK that is seen by researchers that is information provided by SSW services to IUJK licensing applicants. The accuracy of the information displayed on the SSW website is important in online licensing because the applicant does not meet directly with officers only through the website. The accuracy of the information starts from licensing requirements, service mechanism, and contact information that can be contacted by the applicant. As for some information that can be known by the applicant when he wants to take care of IUJK licensing, namely requirements, procedures, legal basis, download form, retribution, time, motto, information service, vision and mission, motto, and our contact or contact information. With this information, the applicant can find out things related to IUJK licensing.

Furthermore, the SSW website has provided information on monitoring of IUJK permit documents. Permit files can be monitored regularly on the SSW website. Through this the applicant will be able to obtain information about the extent of the licensing process that takes place clearly and accurately. Thus the results of the analysis of the Information dimension on the SSW website provided are accurate, current and easy to understand.

\section{G. Ease of Use}

Ease of use, is the ease of use of the website, each website must be user friendly. The quality of IUJK services refers to the convenience of the applicant in using and finding information on IUJK services at UPTSA Kota Surabaya through SSW. On the SSW website has provided information related to IUJK licensing so that the applicant is easy to get IUJK licensing information. In addition, the applicant can also search for information by using interactive means such as telephone and e-mail. This shows that the IUJK online licensing service has made it easy to find information.

The applicant is facilitated in using the SSW website with the presence of an independent ticket window to assist the applicant if they are still unfamiliar with the use of the internet. With the presence of the independent ticket window, the IUJK online licensing service can be used by the entire community. Thus the results of the Ease of Use dimension analysis on the SSW website are easy and user friendly.

\section{H. Government to Business Relations (G-to-B)}

The relation of Government to Business (G-to-B) implementation in the Surabaya Single Window online licensing application process flow is that applicants who want to take care of IUJK licensing can only be done through online stages starting from account registration to completing IUJK licensing file requirements by uploading files on SSW website. So that in the case of IUJK licensing which is initially manual or offline and turned online, it aims to minimize brokering, complicated licensing and to minimize meetings between officers and IUJK licensing 
applicants to avoid bribery in the approval of IUJK licensing. In addition, in the online licensing flow, it can be seen that the UPTSA officer meeting with the applicant only when the applicant wishes to take the ready-made Construction Services Business Permit file

\section{Government to Government Relations (G-to-G)}

According to Surabaya Mayor Regulation No. 26 of 2013 concerning Procedures for Electronic Licensing and Non-Licensing Services in the City of Surabaya, the Surabaya Single Window program is an electronic system used for licensing and non-licensing services in the City of Surabaya, which is accommodated in one integrated system between internal systems at some regional work units.

Collaboration between the regional apparatus units can be seen from the flow of the management of Construction Services Business Licensing in the Surabaya One-Stop Integrated Service Unit. Linkages and forms of Government to Government (G-to-G) collaboration so that online services run well. The relation can be seen in the first stage, namely the applicant registers an account on the Surabaya Single Window website which is a website portal managed by the Surabaya City Information and Communication Office. Furthermore, at the stage of the file verification process carried out by the IUJK back office until the permit file obtains approval for the permit to be issued by the agency, it is carried out by the Cipta Karya and Spatial Public Works Office. Furthermore, at the stage of licensing the Construction Services Business Permit can already be taken by the applicant, in this regard the Surabaya One-Stop Integrated Service Unit as an institution for centralizing licensing services in the City of Surabaya is a place to collect permit documents if the permit for the Construction Services Business License has been issued or finished.

The evaluation activities carried out by the Surabaya One-Stop Integrated Service Unit with the Surabaya City Communication and Information Office and the Cipta Karya and Spatial Public Works Office are the discussion of Monitoring and Evaluation of online licensing on the Surabaya Single Window website. Thus all complaints and disturbances on the SSW website will be taken into account by all Surabaya City Unit Units.

\section{Conclusion}

\section{CONCLUSIONS AND SUGGESTIONS}

In the analysis of the application of electronic-based licensing services (Descriptive Study in Business Licensing Licensing Services Construction Services in the Surabaya One-Stop Integrated Service Unit) found e-Government relations at the stage of the online licensing process flow that is the Government to Business (G-to-B relationship) ) found at the flow stage of the online permit application process. Subsequently, the Government to Government (G-toG) relationship was found in the process flow process for the licensing of Construction Services Business Licensing which involved collaboration between the Surabaya City One-Stop Integrated Service Unit with the Communication and Information Office of Surabaya City and the Public Works Cipta Karya and Spatial Planning Office. City of Surabaya. As for the overall analysis of the application of electronic-based licensing services (Descriptive Study in the Licensing Services Business License Construction Services in the Surabaya One-Stop Integrated Service Unit) can be said to have been good, but there are still applications that are still lacking that is in the dimensions of website design shows that the terms of operation technical problems are still lacking because the applicant still complains about the long loading when uploading the IUJK permit file. Furthermore, the reliability dimension on the SSW website relates to the timeliness of IUJK licensing completion, which is still felt to be inadequate in providing timely services to the applicant, as seen from the inconsistency in file completion time which should have been finished 7 working days to 12 working days. 


\section{Suggestion}

1. The researcher suggests that the Surabaya City Office of Communication and Information add bandwidth on the SSW website so that the applicant can upload the IUJK file smoothly without obstruction wherever the applicant takes care of the permit.

2. It would be better for the SSW website to provide an example of the IUJK licensing requirements form to minimize errors in uploading the IUJK licensing file, besides improving the SSW website information system so that it can provide services without errors.

3. It would be better for UPTSA Kota Surabaya to provide a satisfaction survey to determine the extent of the online licensing service performance of the SSW website. This satisfaction survey is important as a feedback. So, when the applicant receives his licensing documents, the applicant will immediately convey whether satisfied, quite satisfied or not satisfied in managing the permit.

\section{References}

Alanezi, Mohammed Ateeq, et al. 2010. A Proposed Instrument Dimensions for Measuring E-Government Service Quality. International Journal of U- and E-Service, Science and Technology Vol. 3, No. 4, December, 2010.

PETRONAS University of Technology, (http://www.sersc.org/journals/IJUNESST/vol3_no4), accessed on 28 September 2018

Jawapos (Pressreader.com). 2018. Online Systems Need Correction. https://www.pressreader.com/indonesia/jawa-pos/20180519/282235191313712

Kabar24.com. 2016. Surabaya Single Window Services Need Satisfaction Survey Feature. http://kabar24.bisnis.com/read/20160212/15/518669/layanan-surabaya-single-window-perlu-ada-fitursurvei- satisfaction

Molelong, Lexy J. 1996. Qualitative Methods. Bandung: PT Remaja Rosda Karya.

Republic of Indonesia. Surabaya Mayor Regulation Number 26 of 2013 concerning Procedures for Electronic Licensing and Non-Licensing Services. Surabaya

Rianto, Budi and Tri Lestari. 2012. POLRI \& E-Government Applications in Public Services. Surabaya: Putra Media Nusantara.

Rocha, Alvaro et al. 2014. Quality Models of e-Government Online Service Towards a Local Focus, (online). The IEE International Conference on Computer and Information Technology, (http://www.sersc.org/journals) accessed September 28, 2018. 